\title{
ENTRE LUGARES E RELAÇÕES: A CHAPADA DOS NEGROS NAS NARRATIVAS DOS/DAS MORADORES/AS DE ARRAIAS-TO
}

\author{
Rosângila Domingos Gualberto ${ }^{1}$
}

Dernival Venâncio Ramos Júnior ${ }^{2}$

Kênia Gonçalves Costa ${ }^{3}$

\begin{abstract}
Resumo: Esse trabalho analisa narrativas orais sobre eventos relacionados à Chapada dos Negros na cidade de Arraias-TO objetivando conhecer as memórias e as relações socioespaciais estabelecidas com esse espaço. As narrativas foram herdadas dos mais velhos que transmitiram estas memórias de geração a geração. Através das narrativas, foi possível perceber as ricas relações que eles estabelecem com aquele espaço tanto do ponto de vista da temporalidade quanto da espacialidade. O estudo dialoga com autores, como, Lima (2003); Anderson (2008); Tuan (2013) e outros. A análise mostrou que as narrativas orais sobre a Chapada dos Negros trazem histórias que fazem parte da memória da cidade, que articula pertencimento, experiências de um passado, o tempo da escravidão, bem como a um espaço, vestígios materiais e arquitetônicos da Chapada.
\end{abstract}

Palavras-chave: Chapada dos Negros; Memória; Narrativas; Relações socioespaciais.

\section{BETWEEN PLACES AND RELATIONS: THE CHAPADA DOS NEGROS IN THE NARRATIVES OF THE RESIDENTS OF ARRAIAS-TO}

\begin{abstract}
This paper aims to analyze oral narratives about events related to the Black Chapada in the city of Arraias, Tocantins, Brazil, aiming to know the memories and the socio-spatial relationships established with this space. The narratives were inherited from the elders who transmitted these memories from generation to generation. Through the narratives, it was possible to perceive the rich relations that they establish with that space as much the point of view of the temporality as of the spatiality. The study dialogues with authors, such as Lima (2003); Anderson (2008); Tuan (2013) and others. The analysis showed that the oral narratives on the Chapada dos Negros bring stories that are part of the memory of the city, which articulates belonging, experiences of a past, the time of slavery, as well as to a space, the material and architectural vestiges of the Chapada.
\end{abstract}

Keywords: Chapada dos Negros; Memory; Narratives; Socio-spatial relations.

${ }^{1}$ Graduada em Pedagogia (Licenciatura) pela Universidade Federal do Tocantins (UFT). Mestra em Estudos de Cultura e Território (PPGCult) pela Universidade Federal do Tocantins (UFT). E-mail: rosangilagualberto@yahoo.com.br

${ }^{2}$ Doutorado em História pela Universidade de Brasília e Pós-doutorado em Estudos Latino Americanos na Universidade da Flórida. Professor do Curso de História e do Mestrado em Estudos de Cultura e Território (PPGCult) pela Universidade Federal do Tocantins, campus de Araguaína. E-mail: dernivaljunior@gmail.com

${ }^{3}$ Doutora em Geografia pela Universidade Federal de Goiás. Atualmente vinculada a Universidade Federal do Tocantins, Campus Araguaína nas seguintes atividades: Docente/orientadora do Programa de Pós-Graduação em Estudos de Cultura e Território (PPGCult); Pesquisadora do Núcleo de Pesquisa e Extensão em práticas e Saberes Agroecológicos (NEUZA) e Professora Titular, membro do Núcleo Docente Estruturante (NDE) e coordenadora do Laboratório de Ensino e Práticas em Geografia (LEPG) do curso de Geografia; Pesquisadora do Laboratório de Estudos de Gênero, Étnico-Raciais e Espacialidades (LaGENTE-IESA-UFG). E-mail: keniacost@uft.edu.br

Revista da ABPN • v. 11, n. $28 \cdot$ mar - mai 2019, p.242-266 


\section{ENTRE LIEUX ET RELATIONS: LA CHAPADA DOS NEGROS DANS LE RÉCIT DES HABITANTS D'ARRAIAS-TO}

Resumé: L'article vise à analyser les discours liés au lieu connu comme Chapada dos Negros dans la ville d'Arraias, province de Tocantins su Brasil. Le but est de connaitre les mémoires et les relations socio-spatiales établies avec cet espace. Les récits ont été hérités des personnes majeures et ont été transmis de génération en génération. A travers ces récits, il a été possible de percevoir les riches relations qu'ils établissent avec cet espace autant du point de vue de la temporalité que de la spatialité. L'étude dialogue avec des auteurs, tels que Lima (2003); Anderson (2008); Tuan (2013) et autres. L'analyse a montré que les récits de la Chapada dos Negros apportent des histoires faisant partie de la mémoire de la ville, qui articule l'appartenance, les expériences d'un passé du le temps de l'esclavage, ainsi qu'un espacé á travers des vestiges matériels et architecturaux de Chapada.

Mots-clés: Chapada dos Negros; Memorie; Récits; Relations socio-spatiales.

\section{ENTRE LUGARES Y RELACIONES: LA CHAPADA DOS NEGROS EN LAS NARRATIVAS DE LOS/LAS MORADORES/AS DE ARRAIAS-TO}

Resumen: Este trabajo analiza narrativas orales sobre eventos relacionados a la Chapada dos Negros en la ciudad de Arraias, província de Tocantins, Brasil, con el objetivo de conocer las memorias y las relaciones socioespaciales establecidas con ese espacio. Las narraciones fueron heredadas de los más viejos que transmitieron estas memorias de generación a generación. A través de las narrativas, fue posible percibir las ricas relaciones que ellos establecen con aquel espacio tanto el punto de vista de la temporalidad y de la espacialidad. El estudio dialoga con autores, como, Lima (2003); Anderson (2008); Tuan (2013) y otros. El análisis mostró que las narrativas orales sobre la Chapada dos Negros traen historias que forman parte de la memoria de la ciudad, que articula pertenencia, experiencias de un pasado, el tiempo de la esclavitud, así como a un espacio, los vestigios materiales y arquitectónicos de la Chapada.

Palabras-clave: Chapada dos Negros; Memoria; Narrativas; Relaciones socioespaciales.

\section{INTRODUÇÃO}

Este trabalho analisa a memória e os significados da Chapada dos Negros nas narrativas orais dos/as moradores/as de Arraias-TO. O estudo aborda a relação deles/as com o lugar, na proposta de pensar como as narrativas orais, que materializam tais memórias, participam na transformação do espaço em lugar e mostram as relações socioespaciais que os/as narradores/as estabelecem com a Chapada dos Negros.

O município de Arraias iniciou-se no período do ouro, no século XVIII por bandeirantes, com o Arraial da Chapada dos Negros, por volta de 1731. O local foi o início da cidade e está $3 \mathrm{~km}$ de distância da sede do município. Hoje existe o sítio arqueológico com os vestígios do antigo garimpo construído por africanos/as escravizados/as e sobre se contam, na cidade, várias histórias. 
As narrativas sobre a Chapada dos Negros podem ser entendidas a partir do que Barros (2012), afirma: o "[...] narrar é configurar ações humanas específicas, mas é também discorrer sobre significados, analisar situações.” (Barros, 2012, p. 07-08). A todo o momento acionamos o narrar, uma vez que, ao contar uma história, não estamos apenas narrando a continuidade dos atos humanos, mas também conversando sobre os seus significados e os articulando social e pessoalmente.

Narramos, portanto, de diversas maneiras; mas neste texto trataremos das narrativas orais. De acordo com Lima (2003), elas constituem modos de observar e compreender o mundo, desenvolvem moralidades e conhecimentos, e constituem formas expressivas em torno das quais as pessoas e grupos de pessoas dizem sobre suas visões de mundo, seus valores e suas experiências. Estetizamos a vivência através de histórias, mas ao fazê-lo também articulamos experiências e vamos constituindo a memória social. Por isso Nora (1993) afirma que a memória é sempre atual. Está ligada ao presente e se enraíza no espaço, no objeto, na imagem, no gesto, na materialidade das coisas. A continuidade ocorre por meio desta materialidade e das histórias, fazendo com que o passado e o presente permaneçam próximos, ao recorrer à memória, o passado se faz presente e fornece lastro ao agir e às identidades (Cabral, 2014).

Assim, a narrativa "é onde a sociedade se vê e interpreta" (Lima, 2003, p. 24). Talvez por isso, elas estão tão presentes no cotidiano dos moradores da cidade de Arraias. Contá-las significa o fortalecimento e a transmissão de um saber sobre o passado escravista, sucedido de geração a geração. Nesse sentido, "nosso interesse está no que foi lembrado, no que foi escolhido para perpetuar-se na história de sua vida" (Bosi, 1994, p. 37) e para ser contado.

As lembranças ao serem narradas configuram, de diversos modos, a identidade social de um grupo. Mas elas também são produtoras dos espaços vividos (Tuan, 2013), e permitem espacializar os saberes sobre os espaços as quais um determinado grupo social se vincula. Narrativas, identidades e espacialidades, assim, estão intimamente interconectadas na existência social. As narrativas produzidas em parceria com narradores arraianos e analisadas neste texto conduzem as relações identitárias e socioespaciais estabelecidas entre os/as moradores/as de Arraias (TO) com a Chapada dos Negros.

Por fim, as narrativas foram produzidas e gravadas durante a interação entre pesquisadores e interlocutores. Tiveram seu uso autorizado por meio do Termo de 
Concessão de Direitos assinado e pela gravação da autorização em áudio no decorrer das entrevistas. Os áudios e as transcrições das entrevistas estão arquivos no Centro de Documentação História do Campus de Araguaína da Universidade Federal do Tocantins.

\section{LUGAR, MEMÓRIA E RELAÇÕES SOCIOESPACIAIS}

O arraial da Chapada dos Negros, primeiro núcleo de povoamento de Arraias, surgiu por volta do século XVIII, em torno de um garimpo explorado por trabalhadores escravizados. Os traços da presença do garimpo, tais como ruínas, cercas de pedra, casarões antigos, e da cultura afrodescendente como a dança Suça, a Roda de São Gonçalo, a Capoeira, são memórias e saberes afro-brasileiros presentes na cidade. ${ }^{4}$ Para além desses vestígios materiais, as pessoas da cidade contam causos e narram de maneira rotineira eventos associados ao passado aurífero e escravista.

Nessa perspectiva, a Chapada dos Negros, esse espaço - assumido aqui como os restos materiais e arquitetônicos - é tornado lugar ao ser coberto de afetividade e pertencimento, ao serem narradas as memórias sobre o que ocorreu em sua circunscrição.

Para Tuan (2013), o lugar pode ser definido de várias maneiras e entendido como qualquer objeto fixo que atrai nossa atenção. Assim, os nossos olhos se voltam a alguns pontos de interesse. O lugar consiste em um mundo de significado organizado, construído a partir da experiência e dos sentidos (Tuan, 2013). Desse modo, considerando um determinado espaço comum em que, ao adquirirmos um significado de valor e de conhecimento, se transforma em lugar por meio da experiência e dos significados que construímos naquele espaço: “A experiência implica a capacidade de aprender a partir da própria vivência. Experienciar é aprender; significa atuar sobre o dado e criar a partir dele”. (Tuan, 2013, p. 18). Nesse sentido, para o autor, ao inserirmos os objetos e os lugares em um espaço, experienciamos o espaço, e assim atingimos mais objetos e lugares determinados.

Essa experiência humana que são “[...] a vivência real através dos acontecimentos - não é mera sensação: partindo da percepção mais imediata até o

\footnotetext{
${ }^{4}$ Existem diferentes maneiras de escrever a palavra Suça, como Suçia, Sussa e Suscia. Utilizamos neste texto a grafia Suça por esta ser mais próxima da maneira que os/as moradores/as e a região se pronunciam.
} 
julgamento mais mediado, ela é uma sensação significativa - uma sensação interpretada, uma sensação apreendida" (Geertz, 1989, p. 179). Dessa forma, é por meio de símbolos significativos que o indivíduo acha sentido nos acontecimentos vividos por ele, "mas o que de verdade dá sentido a um lugar é o conjunto de significados, os símbolos que a cultura local imprimiu nele, e é isso que leva o outro a sentir, partindo de seus valores, o lugar o qual se visita" (Martins, 2006, p. 39).

Os vestígios de um lugar conhecido por muitas pessoas no presente são as marcas de algo que antes realizava uma utilidade num dado momento histórico no passado. Uma vez que, antes de se degradarem tinha uma função na história, como perderam sua função pelas mudanças históricas, se transformaram num patrimônio histórico e cultural. "Esse conjunto de valores representado pelos significados e símbolos projeta-se no espaço geográfico e, ao mesmo tempo em que dele vai apropriando-se, imprime marcas como que dizendo isto sou eu e, em comunhão com o grupo social, isto somos nós”. (Martins, 2006, p. 40).

Essas marcas deixadas no espaço pelo passado são chamadas, por Santos (2009), de rugosidades. "Chamamos de rugosidade ao que fica do passado como forma, espaço construído, paisagem, o que resta do processo de supressão, acumulação, superposição, com que as coisas se substituem e acumulam em todos os lugares". (Santos, 2009, p. 140).

$\mathrm{Na}$ arqueologia da paisagem, onde se encontram os vestígios da Chapada dos Negros, o espaço é um testemunho de produção de memória, de algo ocorrido antes e que, no cenário atual, não serve mais para o novo, representando um tempo passado. Dessa forma, “[...] a arqueologia da paisagem pouco intervém no registro arqueológico, esforçando-se para mostrar que é possível reconstituir concretamente a maneira como as populações organizaram o seu espaço”. (Morais, 1999, p. 14).

A memória é fundamental na formação da identidade e da cultura de um povo. Ela é socialmente construída, sempre sofre mudanças. Para Pollak (1992), a memória é constituída por pessoas no decorrer da vida e por meio dos elementos de situações vividos pessoalmente e aquelas situações em que o indivíduo se encontra indiretamente num determinado grupo não precisando ter vivido no local, bastando reunir elementos que não se situam no seu espaço/tempo, ou num determinado grupo.

Nessa perspectiva, o sentido da Chapada dos Negros envolve um lugar particularmente ligado às lembranças dos ancestrais que favorece num sentido de 
pertencimento, de construção da identidade cultural e de preservação da memória. Assim, compreende-se que a memória é importante para a existência, preservação e fortalecimento de um grupo, sendo constituinte do processo de construção do efeito de pertencimento. (Anderson, 2008). Por meio da memória reconhecemos e diferenciamos um povo num determinado lugar.

Para Tuan (2013), o lugar é pertencimento e, ao adquirirmos experiências, valores, definição e significado em um determinado espaço, ele transforma-se em lugar, pois, “[...] o lugar é onde guardamos nossas memórias e onde somos nós mesmos". (Tuan, 2013, p. 10). Desse modo, as narrativas orais sobre a Chapada dos Negros são o lugar de produção de sentidos e de hábitos coletivos onde os moradores produzem significado ao lugar onde pertencem. De tal modo, são essenciais no resgate da memória e da interpretação do passado.

As memórias, principalmente as coletivas (Halbawchs, 1990), sempre são uma fonte de pesquisa importante para se entender e espacializar a identidade de um povo, por meio das relações afetivas, do convívio social e das lutas diárias pela sobrevivência. As memórias nos conduzem pelas trajetórias socioespaciais, pois “[...] o espaço, da mesma forma que a sociedade, influencia as trajetórias [...]". (Cirqueira, 2010, p. 43).

Ao referenciar essa relação espacial, Santos (1979) nos aponta que o espaço é um dos objetos sociais que mais impõe, influencia e está intimamente ligado ao cotidiano do indivíduo, comandando a prática social "[...] ingrediente fundamental da transformação da natureza humana, é um dado sócio-econômico, mas também tributário dos imperativos espaciais (Santos, 1979, p.18)". Neste contexto para Cirqueira (2010), a trajetória socioespacial:

[...] envolve a história de vida dos indivíduos, suas experiências dentro de uma temporalidade e uma espacialidade que não possuem uma constituição linear ou contínua. A importância da espacialidade se faz na medida em que as experiências não se dão no nada e, muitas vezes os lugares demarcam momentos e limites dessas trajetórias, firmando-se como referências simbólicas e materiais para o individuo. (Cirqueira, 2010, p. 43).

As trajetórias descrevem a organização social que nos apresenta as vocações comunitárias locais, o papel relevante é o fato da ação comunitária perpassada pela coletividade, em que os atores formalizam os empreendimentos de propriedade coletiva e democraticamente gerida. 
Percorrer o período do ouro na Chapada dos Negros, para Lima (2003), é descobrir um conjunto de imagens e eventos assombrosos que, ao mesmo tempo em que explica a escravidão da época, elabora também uma moralidade assentada de significados. Os/as narradores/as de Arraias expressam os seus valores culturais materiais, imateriais e sociais em torno de seus antepassados que foram escravizados na época da mineração, e estão entrelaçadas e transmitidas de um para o outro, o que se torna importante para a preservação da memória.

\section{GARIMPANDO NARRATIVAS}

Por meio das narrativas, os/as moradores/as de Arraias (TO) reconhecem as suas identidades culturais e suas histórias de vida. Os relatos sobre o imaginário do ouro na Chapada dos Negros revelaram que, ao contar as histórias, os/as narradores/as de Arraias empregaram suas oralidades, entendimentos e interpretações por intermédio da memória e ensinamentos passados pelos/as mais velhos/as. "Os mais velhos transmitem aos mais novos e estes têm a incumbência de dar continuidade às histórias de seu povo, dos seus ancestrais, fortalecendo a ligação entre eles que sobrevive ao tempo. [...]". (Santos Filho; Alves, 2017, p.58).

No imaginário do ouro na Chapada dos Negros estão presentes narrativas orais dos/as moradores/as referentes ao enterro de ouro, aparição e fuga de santa, livusias, visagens e lobisomem. Essas categorias estão relacionadas ao remorso e ao medo que as pessoas sentem do lugar, pois, as histórias de lugares que tiveram início no ciclo do ouro estão associadas a essas percepções pelos seus habitantes. (Lima, 2003).

Existe um conjunto de narrativas por meio do qual os moradores interpretam as histórias de enterro de ouro na Chapada dos Negros, associadas aos ancestrais escravizados, que enterraram os ouros no local. Dona Cheiro narra que:

A história que eu tenho de lá é que o negro deixou muito ouro enterrado por lá $e$... e gente já rancou, um mocado de gente já rancou ouro lá, panela de ouro [...] lata cheia de ouro, garrafão né, tanto que lá tem muito buraco. [...] Esses buracos pequeno redondo fora que tem cá fora é que rancou o ouro que era enterrado. (Entrevista oral realizada com Dona Cheiro em 07 de outubro de 2016). 
Percebe-se que Dona Cheiro afirma que, no local, foram enterrados muito ouro pelos/as negros/as escravos/as. A narrativa atesta que a presença de buracos abertos no local seria a prova de que muitos faiscadores arrancaram esses ouros deixados por seus/suas ancestrais.

Outro relato semelhante sobre o enterro de ouro é de um dos encarregados da Fazenda Guanabara, onde se situa a Chapada dos Negros, o Senhor Joânis de 58 anos, que não é arraiano, mas narra alguns eventos recorrentes no lugar:

Diz que tem ouro deles enterrado aqui em dois lugar, mais será? diz que tem muita assinalada de ouro aí. Enterrado. Que aí foi no tempo da libertação aí já num podia mais mandar ouro pra lugar nenhum é claro né aí.. e muitos já esconderam mesmo né, muitos guardaram né [...] mas diz que aqui na Arraias enterraram um mocado de ouro aí nessa serra. Mas as vêis também pode ser só história. (Entrevista oral realizada com o Senhor Joânis em 04 de setembro de 2016).

A narrativa mostra o motivo do enterro de ouro no local, afirma que o ouro também foi enterrado pelos senhores devido a libertação dos/as escravos/as, pois muitos não tinham o que fazer com o ouro, e dessa forma escondiam com esperança de voltar para buscar.

As histórias de enterro de ouro também estão associadas à igreja católica da cidade. Dona Cheiro conta que: “[...] aquela igreja tem meio metro de grossura ela ainda foi feito por mão de negro feito só de pedra, [...] é grossa, e os trem de senhora dos remédios, os ouro...o dinheiro dela... tá enterrado ali no fundo da casa paroquial". (Entrevista oral realizada com Dona Cheiro em 07 de outubro de 2016).

A narradora ainda relata que, há muito tempo, um padre, antes de partir, mostrou o local do ouro enterrado e designou a tarefa a ela e a um amigo para arrancá-lo.

Ele deu pra Edi marido de Góia e pra mim pra nóis dois rancar, aí Edi queria rancar foi lá falar pro padre e o padre num deixou rancar, o padre Moreira [...]. Ó é cheio de ouro lavrado, panela, cordão de pescoço, pulseira, é relógio, tudo de ouro, tudo, e até a taça do padre beber o vinho, e o santíssimo aquele que o padre levanta assim todo granetado, tudo de ouro. Aí Edi mandou Góia ir lá falar com com Jonas (padre depois do Moreira) se ele deixava rancar, e ele "não, tem nada aqui não tem nada aqui não", quando Góia já ia lá longe Jonas "ó vem cá fia ó cê fala com ele pra mim mostrar o lugar" e ele (marido de Góia) falou "uah! Se ai num tem nada eu não tenho que mostrar lugar", num levou muito tempo acho que foi um ano Edi morreu. (Entrevista oral realizada com Dona Cheiro em 07 de outubro de 2016). 
Narrativas como estas da Dona Cheiro mostram que, de acordo com Lima (2003), o meio da busca pelo ouro enterrado está relacionado à cobiça e à maldição impregnadas pela morte. Quando a narradora conta que "[...] num levou muito tempo acho que foi um ano Edi morreu [...]", mostra que o enterro do ouro torna-se amaldiçoado e lança sua maldição sobre quem o possuiu de forma avarenta.

Segundo Lima (2003),

$\mathrm{Na}$ singularidade dessas concepções, fazendo com que tanto a sua exploração quanto a sua posse sejam consideradas situações amaldiçoadas, é a realização de um movimento de alegorização da escravidão, tramada com os fios de dogmas católicos. (Lima, 2003, p. 195).

Percebe-se que o ouro que se encontra no interior da terra são costumes dos ancestrais de um povo, é carregado de cobiça que leva a maldição, entrelaçado nas crenças da igreja católica. Sinalizam o sinal do escape, do não lugar. As narrativas declaram fenômenos associados em torno do enterro de ouro, que são os conjuntos de histórias que abordam as visagens que aparecem nas proximidades das serras.

Domingas Santana Ponte, de 69 anos de idade, moradora há muitos anos de Arraias, mãe de santo, narra suas percepções sobre o imaginário do ouro:

Eu acho minha fia que foi uma fortuna que Deus tava deixando pros pobres adquiri né, mas do que existiu riqueza isorou né... num deixou os pobre garimpar pra ter o recurso. Que ali se num fosse a maldade do povo ali tava uma rua, uma igreja assim, pro povo ir rezar de vez em quando né e ranjar um ouro que ali já tava liberto pra todo mundo ir com a bateinha bateiar [...] mas a ganância acabou com tudo, até os pobre dos cativeiro acabou não tem mais, cativeiro, aqueles povo bobo que os ricos pegava pra criar. (Entrevista oral realizada com Dona Domingas Santana Pontes em 13 de abril de 2017).

As narrativas de visagens e livusias estão vinculadas à Fazenda Guanabara, situada na Chapada dos Negros, relacionada às visões que os moradores relatam. Não foram encontrados relatos de visagens no local onde estão os vestígios do antigo garimpo.

Ao serem questionados sobre o assunto, os relatos de muitos moradores contam que não há nada desse tipo no local, como conta Joaquim Ribeiro dos Santos “[...] eu nunca vi nada na chapada dos negros. Eu andava na chapada dos negros direto sózim era sózim, olha, eu num digo, as vêis pode ter alguma mais visagem eu nunca vi não [..]” (Entrevista realizada com o Senhor Joaquim Ribeiro dos Santos em 07 de outubro 
de 2016). Da mesma forma, o encarregado da fazenda, o senhor Valdemir Nascimento Maranhão conta que: “[...] eu já vi o pessoal falar de muita história assim de coisa que parece ser paranormal mas eu...eu nunca me deparei com nenhuma situação dessa não, pra dizer que eu vi algo que chamasse atenção não[...]”. (Entrevista realizada com o Senhor Valdemir Nascimento Maranhão em 06 de outubro de 2016).

Mesmo afirmando nunca lhe ter ocorrido esse tipo de situação, Valdemir Nascimento Maranhão narra que "[...] vi uma vez duas luzes paricendo um farol de carro, eu tava lá no posto do japão e vi aqui de lá, tava escurecendo e o local onde tava as luzes não tinha condição de um automóvel passar por ali, meio estranho né”. (Entrevista realizada com o Senhor Valdemir Nascimento Maranhão em 06 de outubro de 2016).

Rosimeire da Cruz, de 43 anos, moradora de Arraias, narra as aparições que ela enxergava nas colinas e que transmitiam nas narrativas dos mais velhos, sobre uma tocha de ouro que os moradores viam nas serras de Arraias.

[...] agora isso aí eu fazia era ver! Eu criança [...]! A gente morava ali na Palmeirinha na roça, e quando era é a boquinha da noite num tinha televisão num tinha nada a gente costumava sentar no terreiro né num banquim lá no terreiro prá ficar ali conversando os mais velhos conversando causo de quem morria essas coisa e a gente ali sentado e e de frente pra onde a gente morava, de frente tinha uma serrona grande.[...], várias vezes, isso eu via eu já era mocinha já eu via aquela tochona [...], saindo de um canto da serra e indo pro outro lado da serra eu via isso aí direto eu via essas coisas. Aí os mais velhos né que era pai e mãe os mais velhos que tava ali falava "ó olha lá ó olha o ouro mudando, é o ouro mudando de lugar". Eles falavam que era o ouro mudando sabe, mudando de um lugar pra outro, era uma tochona [...] cê via aquela tochona caminhando na serra aqui isso eu via demais. Agora hoje eu não vejo isso mais não sei pra onde é que esses ouros mudaram deve ser que foi pro exterior né (risos) porque aqui nunca mais eu vi e ó que aqui próximo de nóis olha o tanto nóis somos cercado de serra né e a gente não ver mais. Mas quando eu morava aqui na roça a gente via isso direto sabe, a tochona passando de um canto da serra pra outro e aí segundo eles era ouro mesmo né, e aí hoje acabou tudo mas realmente essa tocha aí eu vi com meus próprios olhos esse aí eu cheguei a ver né mas aí hoje não tem mais acabou essas coisas tudo. (Entrevista realizada com Rosimeire da Cruz em 27 de novembro de 2016).

O relato de Rosimeire da Cruz diz que, no município, com o fim da escravidão e das atividades de garimpagem, os moradores enxergavam com frequência esse tipo de visagem na serra. 
As narrativas de Valdemir Maranhão e Rosimeire da Cruz estão associadas ao que Lima (2003) caracteriza como imaginário do ouro em Goiás, como a natureza que, de forma sobrenatural, mostra os sinais de veios auríferos. Aparições como esta poderiam tratar-se da mãe do ouro feita de luz, que constitui em visagens percorrendo os céus, girando de uma serra para outra e caindo onde existe ouro.

A "mãe do ouro" composta de luz e determinada de símbolo aurífero, faz parte de um conjunto de mães no universo religioso brasileiro: mãe da água, mãe da mata, mãe do chão, dentre outras, caracterizando em determinados lugares com denominações diferentes. Mas possui atribuições semelhantes que são cuidar do lugar e zelar pela vida dos rios, matas e animais, punir os homens desrespeitosos com a autoridade do encante local, promover o sossego do viajante etc. Podemos compreender a partir de Wawzyniak (2003):

O espaço por eles habitado é subdividido em diferentes áreas, [...] que, além de possuírem características ecológicas específicas, são dotadas de significados próprios e tidas como domínio de seres demitirgicos, considerados seus "donos" ou suas "mães". Eles são reconhecidos como protetores das árvores, dos lagos, dos igarapés, das praias, do rio, [...]. (Wawzyniak, 2003, p. 39).

Os lugares, nesses espaços, geralmente fazem-se morar uma "mãe" ou "dona" que não se sossega apenas aos cuidados referidos, mas a "mãe" também se transforma nos elementos da paisagem dita humana, virando pedra, raiz, buraco, gente, pássaro, peixe, ouro, arco, flecha, cachimbo e até indicando os caminhos do ouro. A "mãe de ouro" acolhe esse componente sobre o ser do mundo, transformacional da cosmologia "afro".

Ao ser questionado sobre as aparições na Chapada dos Negros, o senhor Joânis também encarregado da fazenda na ausência do Valdemir Maranhão, narra e interpreta pensativo a cena, um fato ocorrido com ele na sede se referindo a visagens e livusias, esta última são barulhos que ocorrem em determinados lugares, onde o mesmo relata que:

Jáááá. Tem, é... é montado de cavalo que vem ali, até ali, outra hora toca tamborim no negócio de folia bem aí assim, aí para bem aqui nessa cansela né, [...]. Rapaiz naquela casinha ali eu vi de dia, parecia que era, mas eu num sei se era. Ah, agora aí nesse mato aí eu falo pros meninos aí [...] negócio de onça que aí tem onça né principalmente no inverno aí vem mais nóis já viu elas aí. [...] Agora eu duas vêis eu escutei de dia ali eu num sei se era impressão mas eu num sei, só sei que eu tava deitado lá e aí eu até tava escorando aquele 
barraco lá, aí os menino tinha ido lá pra cima, falô olha, meio dia nóis volta [...] aí eu lá deitado, aí tem um banquim assim né i a água que daqui ligado pra lá pra escorrer assim, aí escutava, as rolinhas e as juriti comendo dentro de casa assim né ficava ouvindo e vráááá aí escutei tchac tchac tchac.... eu digo ah os menino tá vindo, chegando, aquelas butinonas grossas né e vap vap vap aí vem as pisadas dos dois, aí as rolinha e as juriti raaaa e nada aí eu digo uai eles sentaram no banco aí ficou calado! aí eu levantei oiêi e nada, oiêi por de trás da casa assim e digo, então eles passou pra área pra lavar as mão o rosto, nada, deitei de novo, aí tô lá oiando assim, penso que não as rolinha veio e de novo fez assim raaaap aí eu escutava e tchac e tchac e tchac e tchac... eu digo ah rapais agora que eles vem, de lá assim, aí as rolinha de novo aí eu fiquei esperando, e eu digo uai mais esses menino não conversa uai sempre eles é conversador, levantei oiêi nadinha, uai mais de dia assim, eu escutei isso, agora num sei se era, e medo também eu num tenho. [...] eu acho que si você colocar isso na memória um pouco de medo na memória sua, vai acontecer e eu acho que é mais ou menos isso. (Entrevista realizada com o Senhor Joânis em 04 de setembro de 2016).

As narrativas sobre livusias também estão nos relatos de Valdemir Nascimento Maranhão:

Eu tava lá um dia sozinho só eu e meu filho ele foi lá pra cidade e eu fiquei sozinho ali, quando de repente eu ouvi o som de uma flauta né...aí eu ouvi o som de uma flauta e como tava a luz da garagem tava apagada eu fiquei ali, e eu disse vai chegar bem aqui onde eu tô, passou assim ó, tava escuro, mais dava pra ver se alguém tivesse passando por aqui dava pra ver né eu num vi nada assim, e como eu num tenho medo dessas coisas pra mim ficou do mesmo jeito né. [...]. (Entrevista realizada com o Senhor Valdemir Nascimento Maranhão em 06 de outubro de 2016).

Valdemir narra os eventos ocorridos com pessoas que dizem ter presenciado situações semelhantes.

Morava um sinhor aí apelidado de mineiro e ele contou pro deputado que tava um dia sozinho aí e quando ele ouviu os cachorro brigando e não tinha cachorro aí na propriedade, foi uma briga intensa e ele saiu pra ver e diz que só via o barulho mas não via... num via nada, nenhum cachorro, isso ele contou pro dono daqui da propriedade. Agora eu nunca vivi nenhuma situação dessa pra dizer assim ó eu vi. [...]. Tem um senhor por nome de Lino, que sempre vem aqui e tem o Vanderley ele estava num lugar ali que nóis apelidamos de morro vermelho porque as terras e lotes tudo são grande e lá é...e lá a terra é bem vermelha então a gente pegou e criou esse nome pra esse lugar. Eles tava ali e ouviram um grito, dizendo ele que era muito assombroso uma coisa muito estranha e eles largaram lá o local e vieram pra sede chegou e falaram num dá pra ficar ali não. (risos) é muito... é muito feio. Então eu vejo história assim, mas eu nunca me deparei com a situação dessa. [...] Já ouvi daqui, as coisas que o pessoal conta daqui, que viram, o Joânis mesmo diz que tava ali um dia quando fechou uma porta de aço ali... (Entrevista realizada com o Senhor Valdemir Nascimento Maranhão em 06 de outubro de 2016). 
O senhor Joânis também conta relatos de visagens ocorridos com outras pessoas na fazenda.

Isturdia teve o Osmar mais o filho dele aqui vieram aqui passou dois dias [...] mas outros tempos uns anos atrás aí eles tavam acampando naquela casinha aí eles foi fazer precisão no mato ali tem uma moitinha de mato [...] ele tava lá, aí quando pensa que não a luz veio vuи clariou tudo assim e ele saiu da carreira de lá pra cá moço num aperto e aí é assim. Quando é agora ele diz que tava bem aqui e diz que tava truvando diz que vinha um cavaleiro bem dali e virou pra li e eu acho que isso tá mais é na memória. (Entrevista realizada com o Senhor Joânis em 04 de setembro de 2016).

Percebe-se, diante das narrativas, que os narradores não temem essas aparições. Valdemir Maranhão conta: “[...] eu acredito que a maior parte desses negócio de livusia essas coisas, é medo que faz isso aí, eu num sou medroso pra essas coisas não, [...] aqui tem fama de muita coisa assim estranha né, [...]”. (Entrevista realizada com o Senhor Valdemir Nascimento Maranhão em 06 de outubro de 2016).

José Reginaldo narra que:

Ah, mentira desse povo. É coisa de, eu vejo só coisa de medroso, tem gente, “ah eu fiquei sabendo que aconteceu isso, ah foi com um cara que tava aqui que aconteceu”. [...] Isso é pra gente medroso [...] pessoa medroso escuta trem ele vê coisa, é tanta coisa que vê, eu num vejo nada. (Entrevista realizada com o Senhor José Reginaldo Ferreira de Moura em 26 de março de 2016).

O fato de os moradores não temerem o que veem de estranho no local, está relacionado ao fato de que, muitas vezes, o medo pode estar na nossa mente e que, quanto menos pensamentos tivermos, menos medo sentimos de um lugar. (Tuan, 2005). "A imaginação aumenta imensuravelmente os tipos e a intensidade de medo no mundo dos homens. Assim, nossas mentes férteis são uma abençoada mistura” (Tuan, 2005, p. 11). Joânis confirma isso ao ter narrado "[...] eu acho que si você colocar isso na memória um pouco de medo na memória sua, vai acontecer e eu acho que é mais ou menos isso".

Segundo Tuan (2005, p. 334), “[...] o medo não é apenas uma circunstância objetiva, mas também uma resposta subjetiva. Uma paisagem de cadafalsos e forças é objetivamente uma paisagem do medo". Parafraseando Tuan (2005), as diferentes manifestações das forças e a construção humana permanecem para conter-se o medo. 
As narrativas de livusias e visagens na Chapada dos Negros estão relacionadas aos fantasmas, “[...] os fantasmas são pessoas mortas que, em algum sentido, ainda estão vivas. Eles podem ser reconhecidos somente pelos seus efeitos, como uma porta que range". (Tuan, 2005, p. 179). Para o autor, os fantasmas fazem rumores de movimentos de pássaros e de outros animais. Percebemos isso quando Valdemir Maranhão narra os barulhos de uma briga de cachorros "ele ouviu os cachorro brigando e não tinha cachorro aí na propriedade, foi uma briga intensa e ele saiu pra ver e diz. que só via o barulho mas não via... num via nada, nenhum cachorro”.

Para Tuan (2005), os fantasmas ainda podem ter formas e expressões humanas reconhecíveis, mas necessitam da materialidade inteira de um ser humano vivo, "quando é agora ele diz que tava bem aqui e diz que tava truvando diz que vinha um cavaleiro bem dali e virou pra li", podem aparecer como remoinhos, focos de incêndio ou objetos escuros indefinidos, "aí quando pensa que não a luz veio vииии clariou tudo assim e ele saiu da carreira de lá pra cá moço num aperto e ai é assim”.

Joânis ainda narra sobre o que as pessoas dizem para ele diante dessas assombrações na fazenda sede:

Aí ele falou assim, rapaiz e como é que tu fica aqui sózim, eu digo é ruim, eu fico aqui sózim quando o sol vai se pondo é hora mais ruim. Depois da meia noite depois de tantas horas a gente acustuma com o horário da noite, mais quando vai truvando, é cuma assim, quando o dia vai se dispontando que ocê ver clarear na brécha da da casa assim, que ocê acorda cê diz ôpa aí cê escuta passarim cantar aí ocê diz ah vai nascendo o dia, tudo nascendo é alegria, aí quando o sol vai se pondo é tipo assim terminando alguma coisa morrendo alguma coisa, é uma impressão, se ocê tiver só, se ocê tiver só fica pior, mais num é medo de de visagem não, eu tenho medo de passar mal sózim. (Entrevista realizada com o Senhor Joânis em 04 de setembro de 2016).

Essas narrativas dos moradores atravessam nas interpretações ao mesmo tempo em que estabelecem conjuntos de valores morais que são formas de conhecimentos da sua história e do mundo.

Outras narrativas em torno às serras que circundam a região da Chapada dos Negros que os moradores relatam, estão associadas ao dogma e religiosidade, e se interligam também à história do município, é a narrativa da aparição e fuga da santa, a Nossa Senhora dos Remédios.

Quem narra é Dona Cheiro: 
Bom, eu já vi a história, só que eu não sei se a história tá do jeito que se é verdade... Eu já vi falar que a santa era dos negros. Agora eu num sei se eles trouxeram ela pra aí e se ela apareceu aí. Eu sei é que eles trazia quando eles mudaram pra cá eles traziam ela e ela num ficava, e aí trazia e ela num ficava...ela foi até marrada no pau pra ver se ficava mas num ficou só veio ficar depois que mandou fazer a capela dela. Porque lá já tinha a capela dela né tá lá. [...] Aí a santa quando eles fizeram a capelinha dela ela ficou aí a santa é Nossa Senhora dos Remédios fizeram a igreja aí e aí ela ficou. [...] As águas de lá de cima foi acabando ficando pouquinha eles mudaram o garimpo pra aqui e trazia ela, mas trazia ela hoje e amanhã ela manhecia lá eles marraram ela até no pau aqui, aí só parou depois que fez a capela aqui que ela parou. (Entrevista oral realizada com Dona Cheiro em 07 de outubro de 2016).

Percebe-se que a narrativa da Dona Cheiro mostra que a santa foi encontrada na Chapada dos Negros na época do antigo garimpo pelos escravos, que com a escassez da água no local, mudaram o garimpo para onde hoje se fundou a cidade. Porém, a santa não permanecia em sua nova morada, ela fugia para o seu local de origem, a Chapada dos Negros.

A recusa da santa em não permanecer no local diferente de sua origem pode ser entendida pelo fato de aquele lugar não proporcionar abrigo, aconchego e pertencimento, ou seja, não existir nesse novo local a sua morada, pois, depois de feita a sua capela, acabou-se a fuga.

Observamos outra narrativa do aparecimento e fuga da santa na versão de Francisco Carvalho Souza. Ele narra que a santa foi encontrada por uma escrava:

De Nossa Senhora eu ouvi falar que...por isso deram o nome nossa senhora aqui porque foi encontrada uma imagem lá... e se eu não me engano foi por escravo que encontrou essa imagem, nossa senhora de escravos, não foi nem um homem foi uma mulher que encontrou essa imagem de Nossa Senhora. [...] trazia botava cá quando voltava ela aparecia no mesmo lugar num sei se é lenda ou se é verdade, mas existe a história sim. (Entrevista oral realizada com o Senhor Francisco Carvalho Souza em 07 de outubro de 2016).

Diran Batista Cordeiro Moura narra a história da santa da forma que os mais velhos contavam:

A história que eu sei sobre a imagem de Nossa Senhora dos Remédios é que realmente ela foi encontrada na Chapada dos Negros. De lá como era muito acidentado o lugar, trouxeram essa imagem aqui pra esse local onde hoje está a igreja e onde hoje foi construída a cidade né. Mais ela não permaneceu, puseram aí, quando vieram à tarde no outro dia cedo ela não estava no lugar. Aí foram procurar encontraram a imagem lá na Chapada dos Negros onde ela tinha sido encontrada. Novamente trouxeram e a mesma o mesmo fato 
aconteceu por mais duas vezes. Então eles resolveram construir uma igreja e dar o nome de Nossa Senhora dos Remédios. (Entrevista oral realizada com Dona Diran Batista Cordeiro Moura em 26 de novembro de 2016).

Diran ainda narra o motivo pelo qual puseram o nome da santa encontrada de Nossa Senhora dos Remédios:

Porque naquela época tudo o que vinha de comércio, medicamento, gêneros alimentícios, roupas, calçados, tudo vinha da Bahia mais precisamente de Barreiras que era cidade mais próxima do estado de Goiás na época. E então, ela...assim, trouxeram alguns medicamentos também e era com esses medicamentos que as pessoas medicavam os casos de doença da cidade das pessoas que aqui se encontravam, na chapada ainda né. E como a imagem apareceu e eles não sabiam o nome da santa, então eles falaram olha vamos chamá-la de Nossa Senhora dos Remédios porque é com ela que nós vamos nos apegar pra que os remédios seja realmente bons que façam efeitos curativos pras nossas doenças, doenças do nosso povo. E assim foi construído a igreja e o nome da santa passou a ser Nossa Senhora dos Remédios, e a igreja também leva o seu nome, Igreja Matriz Nossa Senhora dos Remédios. Isto é uma história que eu ouço e já ouvi de alguns antepassados. (Entrevista oral realizada com Dona Diran Batista Cordeiro Moura em 26 de novembro de 2016).

$\mathrm{Na}$ busca de significado para esse evento, percebe-se que a narradora relata a escolha do nome da santa devido ao fato de se apegarem a ela pela bênção dos remédios e de medicamentos que chegavam "olha vamos chamá-la de Nossa Senhora dos Remédios porque é com ela que nós vamos nos apegar pra que os remédios seja realmente bons que façam efeitos curativos pras nossas doenças, doenças do nosso povo”. A narrativa de Dona Diran mostra que a construção da igreja fez com que a santa finalizasse as fugas, "então eles resolveram construir uma igreja e dar o nome de Nossa Senhora dos Remédios".

De acordo com Lima (2003), as narrativas em torno do aparecimento e fuga de santos são acontecimentos extraordinários que significam também proteção divina, é um fato que insere o maravilhoso no registro das experiências fatuais dessa história.

Para Galvão (1976, p. 31), “[...] os santos podem ser considerados como divindades que protegem o indivíduo e a comunidade contra os males e infortúnios". Dessa forma, o aparecimento da santa na Chapada dos Negros o apego das pessoas por ela, significam um amparo milagroso que amenizava os problemas e as enfermidades da época. 
A narração de sinais que se inserem no ambiente do ouro na Chapada dos Negros também apresenta acontecimentos relatados nas narrativas dos moradores sobre figuras celestes, o lobisomem.

Em Arraias viveu um homem de nome Elesbão. As narrativas em torno de Elesbão estão associadas às histórias de lobisomem que povoam o imaginário da Chapada dos Negros. Conta-se que Elesbão era um homem que andava sempre maltrapilho, acreditava-se que ele virava lobisomem e que se escondia na Chapada dos Negros para praticar o seu ritual, pois muitos escutavam os seus urros.

O senhor José de Moraes narra que: “[...] diz que ele virava lobisomem né, tinha esse papo aí né, toda quaresma. Eu acho que os pais pra não deixar a gente ficar na rua, eles falava ó o Elesbão é vem aí ó, o lobisomem." (Entrevista oral realizada com o Senhor José de Moraes em 19 de julho de 2016). O morador José Reginaldo complementa que: "Elesbão era um negro né daqui de Arraias negro velho que também tinha a descendência forte de escravo e o local dele esconder era na Chapada dos Negros". (Entrevista oral realizada com o Senhor José Reginaldo Ferreira de Moura em 26 de março de 2016).

Percebe-se que as histórias de lobisomem em torno à Chapada dos Negros são adquiridas de singularidade local. Os moradores de Arraias narram sobre o lobisomem na Chapada dos Negros por meio de Elesbão, um homem negro que há muitos anos viveu na cidade, que com sua crença de virar lobisomem amedrontava as pessoas, pois, muitos tinham medo de Elesbão realmente virar um lobisomem.

As narrativas estão associadas ao tempo da quaresma onde também forma o tempo das histórias de lobisomem, pois, “[...] nas horas mortas, à meia-noite, antes de o galo cantar são os momentos propícios da extraordinária conversão”. (Lima, 2003, p. 192). Nesse sentido, parafraseando Lima (2003), o tempo da quaresma marca essas transformações: nas noites de lua cheia, essas figuras percorrem os espaços da cidade e dos matos provocando temores aos moradores.

Elesbão amedrontava os moradores pelo fato de viver sempre maltrapilho, além de virar lobisomem. Observamos a narrativa do morador José Reginaldo, “[...] eu ficava com medo, o pessoal falava assim, não lá é negócio de escravo, de nativo avemaria vem embora dali era Elesbão que mora lá!”. (Entrevista oral realizada com o Senhor José Reginaldo em 26 de março de 2016). 
Nessa perspectiva, percebe-se que o medo referente à Chapada dos Negros está relacionado à forma como as pessoas mais velhas contavam para os mais novos as histórias que existiam no lugar. O fato de "eu acho que os pais pra não deixar a gente ficar na rua, eles falava ó o Elesbão é vem aí ó, o lobisomem," é uma forma que, para Tuan (2005), consiste de colocar medo nas crianças, o que sempre foi um método comum para discipliná-las.

Alguns dos eventos simbólicos e significativos na Chapada dos Negros também estão presentes em livros. Cordeiro (1989) registra em seus escritos sobre Arraias os sonhos que antigamente existiam referentes à Chapada dos Negros e que a figura do Elesbão participava em alguns sonhos das pessoas:

Certa vez, um nordestino que nunca ouvira falar de Arraias, sonhou com muito ouro na Chapada dos Negros. Veio em procura da cidade, não acertando com o local, chegou a Natividade, [...]. De lá, indicaram-lhe o caminho e, ao chegar, por coincidência, encontrou-se com Elesbão, único morador dos velhos escombros da rica Chapada, que lhe havia aparecido em sonhos. Elesbão levouo ao lugar descrito, oferecendo-lhe seu trabalho braçal, confiante na promessa de participação no lucro. Ao ver, porém, os sinais do tesouro enterrado, o sagaz nordestino pediu ao companheiro para ir à cidade, que não ficava longe, para trazer-lhe suprimentos alimentares. Enquanto Elesbão cumpria fielmente a missão que lhe foi confiada, o esperto companheiro encheu-se de ouro e sumiu. (Cordeiro, 1989, p. 21).

A autora registra outro sonho referente à Chapada dos Negros, este sem a presença de Elesbão:

[...] D. Lina, esposa de Mestre Aniceto, que ensinou música e regeu a Filarmônica OITO DE SETEMBRO, em Arraias, teve um sonho. O casal morava, nesse tempo, em Anápolis. D. Lina, quando acordou, chamou o Mestre Aniceto e contou-lhe o ocorrido. $\mathrm{O}$ mestre não mais conciliou o sono e, bem cedo, conseguiu de seu genro um caminhão e no qual se foi com a esposa, e arrancharam-se na Chapada dos Negros. Convidaram, então, o seu velho amigo Mamédio, que residia na cidade de Arraias, de onde era filho, pertencente a família, conhecida como honesta e trabalhadora. E do mesmo modo que o nordestino fez a Elesbão, fizeram ao companheiro amigo, que ao voltar da cidade, com os víveres para refazer a cozinha, já o caminhão sumia na curva do caminho para o Sul, com o casal. Ele só encontrou no lugar a marca do garrafão de ouro em pó, do sonho contado por D. Lina. [...]. (Cordeiro, 1989, p. 21).

Os sonhos também foram meios de atrair pessoas de outras localidades pela procura do tesouro, pessoas que não conheciam aquela região, mas que vinham em 
direção ao lugar desse ouro que lhe apareceu em sonhos. A presença do Elesbão no sonho do nordestino indicando o local onde o ouro estava enterrado está associada ao fato de ele ser um morador daquele lugar e, portanto conhecia o local e saberia guiá-lo até os veios auríferos.

Podemos perceber que os sonhos também são relacionados à temática do ouro depositado no interior da terra seguida da avareza atribuída pelos ricos que foram enriquecidos às custas do trabalho escravo. Para Lima (2003), esses sonhos são fenômenos que falam da história local e constroem moralidades.

Outro acontecimento no sítio imaginário do ouro da Chapada dos Negros se encontra também nos registros de Cordeiro (1989), a autora aborda que:

Contam que, na grande Chapada, havia pepitas de ouro como raízes de mandioca, cultivada em terra apropriada, com a dimensão de até seis centímetros de comprimento, amontoadas umas sobre as outras que, não raras vezes, foi preciso cortar algumas a machado, para poder-se extrair outras. De certa feita, encontraram uma a que deram o nome de MOLEQUE, pois tinha a forma de uma criança. Era tão pesada que escadeirou um burro para ser conduzida dali à fazenda do dono da cata. $\mathrm{O}$ caminho era montanhoso. (Cordeiro, 1989, p. 08).

Joaquim Ribeiro dos Santos narra este acontecimento:

Agora eu num vi, o povo comenta que lá tiraram esse moleque de ouro diz que foi um moleque diz que era um moleque de ouro desse tamanho mas eu num credito, num vi. [...]. Porque essa pedra de ouro da serra pelada essa todo mundo viu i ela era pequeninha assim 60 quilo (risos) agora essa aqui num vejo falar no peso... só ver a história, [...]. (Entrevista oral realizada com o Senhor Joaquim Ribeiro dos Santos em 20 de julho de 2016).

Rosimeire da Cruz conta uma narrativa que a sua mãe já falecida contava para ela sobre o ouro em Arraias.

Mãe contava uma história de que aqui era tão rico de ouro tão rico que quando chovia as pessoas saiam né é...quando passava a chuva assim as pessoas saía naquela enchorradinha catando pedrinha de ouro sabe, que diz que as pedrinha de ouro escorria de tanto que tinha aqui em Arraias diz que ás vezes as galinhas via aqueles trenzim brilhando saía saía é...é... pinicando catando o ouro, diz que era ouro de tanto que tinha ouro aqui em Arraias. Nossa! isso aí mãe contava demais e as pessoas mais antigas os mais antigos eles falam que era verdade mesmo que aqui era cidade do ouro mesmo que tinha muito ouro. (Entrevista oral realizada com Rosimeire da Cruz em 27 de novembro de 2016). 
Diante das narrativas do imaginário do ouro na Chapada dos Negros, entende-se que a memória constitui de diferentes elementos. Ao contarem sobre os acontecimentos do passado da região transmitidos pela memória coletiva, os narradores traçam outras formas sobre aqueles eventos, enriquecendo-os com novos formatos, pois, "[...] a memória é seletiva. Nem tudo fica gravado. Nem tudo fica registrado". (Pollak, 1992, p. 203). Isto é, o vivido não surge em nenhum momento na sua integralidade, mas mediante recortes a partir do que se mostra como significativo e afetante para o sujeito do presente, onde se produz a memória.

Observa-se que, para Tuan (2013), o espaço se transforma num lugar quando se adquire valor, experiência, assim, os conjuntos de significados atribuídos é que dão sentido a um lugar. Desse modo, à medida que os/as narradores/as por meio da experiência narrada transformam o espaço em lugar e produzem sentidos ao narrado, "o narrador tira o que narra da própria experiência e a transforma em experiência dos que o escutam”. (Bosi, 1994, p. 95).

Quando os moradores narram sobre suas lembranças do passado pelas narrativas dos acontecimentos do lugar, ao mesmo tempo recordam eventos que marcaram de alguma maneira as suas vidas. Eles contribuem para a preservação desse passado, para que essas lembranças não se apaguem.

Para Anderson (2008), a preservação dessa memória é também uma forma de resistência ao esquecimento. Mantê-las vivas é uma forma de demonstrar sentimento, pertencimento dos moradores com o lugar e de construir o próprio lugar. A lembrança e a relação com o passado significam laços de identidades culturais dos moradores.

Com a ocupação do espaço em torno às atividades do garimpo, surgia o pequeno povoado na Chapada dos Negros, iniciados pela busca incessante de ouro e dos sinais auríferos, construindo o que Lima (2003) chama de um lugar impregnado de eventos alegóricos e admiráveis. Já que para Tuan (2013) o lugar é definido de diversas maneiras e em escalas diferentes, entende-se que o lugar constituído naquele tempo, era o lugar do ouro. Hoje, o espaço que antes era de escravidão, deu lugar a narrativas e significados arrodeados de valores morais conduzidos pela memória daqueles acontecimentos por intermédio das narrativas de seus descendentes.

Os significados estão entrelaçados ao lugar e à memória de um tempo designado pelo sofrimento "desumano" e das lembranças de inferioridade dos antepassados. 
Francisco Carvalho Souza narra em seu imaginário com um semblante triste, o sofrimento "desumano" de seus antepassados e os remorsos que sente ao frequentar o local:

O sofrimento pra trabalhar, o trabalho escravo, eu tenho um remorso muito grande, toda vez que eu vou lá eu sinto, lembro mesmo da escravidão porque realmente é penoso fica triste, oh só quem não tem coração que não sente. [...] A gente vai tranquilo sem carregar nada, chega lá em cima cansado morto de cansado! Quero saber quem tá lá em cima trabaiando carregando é...sacos de terra que eles carregava o cascalho era em sacos né que a gente sabe a história carregava em sacos no ombro né e morrendo de apanhar ainda. [...] Então o que eu sinto dali é remorso mesmo, sofrimento que eles passavam. Chega me arripêia [...] o sofrimento que esses povo nosso passaram sem ganhar... em troco de nada que as vêis nem alimentar direito num alimentava. Que a gente sabe nunca existiu coisa pior que a escravidão, escravidão pra mim foi a pior muito desumano, pior do que tudo, ditadura...de tudo. (Entrevista oral realizada com o Senhor Francisco Carvalho de Souza em 07 de outubro de 2016).

Este aspecto significativo da memória de Francisco mostra que "em face dessa lembrança traumatizante, o silêncio parece se impor [...]. E algumas vítimas, que compartilham essa mesma lembrança 'comprometedora', preferem, elas também, guardar silêncio". (Pollak, 1989, p. 04). O tempo marcado pelo sofrimento "desumano" como trata a narrativa de Francisco Carvalho de Souza, pode levar a necessidade de esquecimento do lugar pelos moradores, pois, "do ponto de vista dos negros, talvez os eventos daquele tempo não mereçam mesmo compor suas biografias atuais, já que eles desencadeiam somente as lembranças da condição de subalternidade de seus antepassados escravos". (Lima, 2003, p. 127).

Os relatos sobre o imaginário do ouro na Chapada dos Negros são elementos da identidade afro-brasileira que trazem uma riqueza cosmológica nas narrativas dos moradores. As narrativas de Rosimeire Cruz sobre uma tocha de fogo na serra representam para Eliade (1969) uma abordagem simbólica que, divulgados por determinados tipos de cultura, circularam no mundo por meio de criações culturais elaboradas por certas sociedades humanas e compreendidas por povos que às outras sociedades não teriam conhecido de outra maneira. Elas remetem todo o imaginário do mundo e dos existentes, tanto em outras culturas como nas terras subterrâneas.

De acordo com Lima (2003), as narrativas em torno do enterro de ouro sejam por forma da natureza indicando os veios auríferos, ou pelo enterro arrodeado de cobiça dos costumes antigos. De qualquer maneira, esse ouro enterrado era amaldiçoado causando até a morte daqueles que desejam possuí-lo de forma avarenta, trazem 
sentidos ligados à riqueza e ao sofrimento, pois a riqueza de uns ocasionava o sofrimento de outros. Em Arraias, durante algum tempo, predominou em algumas pessoas o hábito em escavar o fundo da igreja a fim de encontrar os ouros enterrados no local, constituído de crenças católicas, como consta nas narrativas de Dona Cheiro.

Concordando com Khoury (2001), as narrativas revelam que a experiência permeia-se de imagens, memórias e sentimentos. São expressões de práticas sociais por meio das quais os sujeitos se constituem historicamente. Experiências narradas e recordadas ocorrem de múltiplas temporalidades que se misturam, intervindo em seu emocional e em suas práticas diárias.

A especificidade das narrativas coletadas em Arraias sobre a Chapada dos negros é o que constrói uma interpretação de eventos por meio de seus sinais simbólicos. Os/as narradores/as contam sobre a sua cidade e os acontecimentos que formam o passado e constituem o presente de suas gentes. As explicações daquele passado pelos moradores atuais faz com que as pessoas ouvintes atribuam o papel de interpretação dessas narrativas de diferentes formas.

\section{CONSIDERAÇÕES FINAIS}

Este estudo representa um exercício de busca pela compreensão dos significados, temporalidades e espacialidades por meio de narrativas, assim conhecendo as relações socioespaciais atreladas às memórias e lugares da Chapada dos Negros. $\mathrm{O}$ trabalho aprofunda em um lugar representado por uma arqueologia, mas não a física, no sentido de escavar, mas aquela da memória que representa a dinâmica de preparar os achados, ordenar as peças onde a paisagem representam as marcas que constituíram o passado e formam o presente dos/as moradores/as de Arraias.

Entendemos que as narrativas constituem o espaço da Chapada dos Negros em lugar. Ao narrarem os acontecimentos do passado da região, os moradores recordam eventos que marcaram, de alguma maneira, as suas vidas. Do mesmo modo, contribuem para a preservação desse passado, para que essas lembranças não sejam silenciadas.

As narrativas do imaginário do ouro na Chapada dos Negros trazem histórias que fazem parte da memória da cidade, que são as experiências da tradição oral, cheias de sentidos que atribuem significados ao lugar, de pertencimento, experiências, de 
memória em que, por meio de conhecimentos herdados dos mais velhos repassam a conservação desses saberes.

Consideramos que as pessoas envelhecem e memórias são esquecidas e apagadas em partes, outras se perdem com o tempo. Mas o esquecimento valoriza as lacunas, fazendo com que não seja somente uma ausência ao recorrer o exercício da memória, mas o esquecimento também é uma forma de encobrir algo. No caso da memória da Chapada dos Negros, as suas narrativas são um encobrimento, em que se narra também para lembrar ou para legitimar essa memória.

Uma forma de preservar essa memória de um total esquecimento são as narrativas do povo que, ao manter essas narrativas escritas de alguma maneira, contribuem para a preservação do pretérito de suas gentes. A atuação dessa memória no presente é o que a torna social e cultural no contexto, estabelecendo inúmeras relações socioespaciais, que por meio do espaço geográfico da Chapada dos Negros, constrói as memórias através das narrativas sobre livusias, fantasmas, a Santa, lobisomem, moleque de ouro, tocha de fogo e a escravidão para descrever e perpetuar a história da região, ambiente múltiplo, cheio de simbolismos e disputas.

\section{REFERENCIAS}

ANDERSON, Benedict R. Memória e esquecimento. In: Comunidades imaginadas: reflexões sobre a origem e a difusão do nacionalismo. São Paulo: Companhia das Letras, 2008.

BÁ, A. Hambaté. A tradição viva. In: UNESCO. História Geral da África I: metodologia e pré história da África. Brasília, 2010.

BARROS, José D'Assunção. Tempo e Narrativa em Paul Ricoeur: considerações sobre o círculo hermenêutico. Fênix - Revista de História e Estudos Culturais. Rio de Janeiro. Vol.9, n 1, 2012, p. 01-27. Disponível em: http://www.revistafenix.pro.br/PDF28/Artigo_9_Jose_D_Assuncao_Barros.pdf. Acessado em: 12 de Julho de 2017.

BOSI, Ecléa. Memória e Sociedade: lembranças de velhos. $3^{a}$ ed. São Paulo: Companhia das Letras: 1994.

CABRAL, Maryana Petry. No tempo das pedras moles: arqueologia e simetria na floresta. Tese (Doutorado)- Universidade Federal do Pará, Instituto de Filosofia e Ciências Humanas, Programa de Pós-Graduação em Antropologia - UFPA, Belém, 2014.

CIRQUEIRA, Diogo Marçal. Entre o corpo e a teoria [manuscrito]: a questão étnico-racial na obra e trajetória de Milton Santos. Dissertação de Mestrado - Programa de Pós-Graduação do Instituto de Estudos Sócio-Ambientais. Goiânia: UFG, 2010. 
CORDEIRO, Rosolinda Batista de Abreu. Arraias: suas raízes e sua gente. Goiânia: 1989.

ELIADE, Mircea. Imagens e símbolos: ensaios sobre o simbolismo mágico-religioso. São Paulo: Artes e Letras/Arcadia: 1969.

GALVÃO, Eduardo. Santos e visagens: um estudo da vida religiosa de Itá, baixo Amazonas. Brasília: INL: 1976.

GEERTZ, Clifford. A Interpretação das Culturas. Rio de Janeiro: LTC: 1989.

HALBWACHS, Maurice. A Memória Coletiva. São Paulo: Editora Revista dos Tribunais:1990.

KHOURY, Yara Aun. Narrativas orais na investigação da história social. Projeto História, n. 22, 2001, p. 79-103. Disponível em: http://revistas.pucsp.br/index.php/revph/article/view/10731/7963. Acessado em: 25 de novembro de 2016.

LIMA, Nei Clara de. Narrativas orais: uma poética da vida social. Brasília: Universidade de Brasília: 2003.

MARTINS, Clerton. Patrimônio cultural e identidade: significado e sentido do lugar turístico. In: (org.) Patrimônio cultural: da memória ao sentido do lugar. São Paulo: Roca, 2006.

MORAIS, José Luiz de. A arqueologia e o fator geo. Revista do Museu de Arqueologia e Etnologia, vol. 9, 1999, p. 3-22. Disponível em: http://www.revistas.usp.br/revmae/article/view/109339. Acessado em: 03 de dezembro de 2016.

NORA, Pierre. Entre Memória e História: a problemática dos lugares. Projeto História, vol. 10, dez. 1993, p. 7-28. Disponível em: http://revistas.pucsp.br/index.php/revph/article/view/12101/8763. Acessado em: 21 de junho de 2016.

POLLAK, Michael. Memória e Identidade Social. Revista de Estudos Históricos, v. 5, n. 10, 1992, p. 200-212. Disponível em: http://www.pgedf.ufpr.br/memoria\%20e\%20identidadesocial\%20A\%20capraro\%202.p df. Acessado em: 08 de maio de 2019.

$\begin{array}{cccc}1989, & \text { 3-15. } & \text { Disponível } & \text { em: }\end{array}$ http://www.uel.br/cch/cdph/arqtxt/Memoria_esquecimento_silencio.pdf. Acessado em: 28 de novembro de 2016.

SANTOS FILHO, Eudaldo Francisco dos; ALVES, Janaína Bastos. A tradição oral para povos africanos e afrobrasileiros: relevância da palavra. Revista da Associação Brasileira de Pesquisadores/as Negros/as (ABPN), v. 9, 2017, p. 50-76. Disponível em: http://abpnrevista.org.br/revista/index.php/revistaabpn1/article/view/464. Acessado em: $16 \mathrm{de}$ outubro de 2018.

SANTOS, Milton. Sociedade e Espaço: a formação social como teoria e como método. In: Espaço e Sociedade. Petrópolis: Vozes: 1979. 
A natureza do espaço: Técnicas e Tempo, razão e Emoção. São Paulo: Editora da Universidade de São Paulo: 2009.

TUAN, Yi-Fu. Espaço e lugar: a perspectiva da experiência. Londrina: Eduel: 2013.

Paisagens do medo. São Paulo: UNESP: 2005.

WAWZYNIAK, João Valentin. "Engerar": uma categoria cosmológica sobre pessoa, saúde e corpo. Ilha, v.5, n.2, 2003, p. 33-55. Disponível em: https://periodicos.ufsc.br/index.php/ilha/article/view/15357/15348. Acessado em: 24 de fevereiro de 2017. 